\author{
Czesław Machelski \\ prof. dr hab. inż. \\ Politechnika Wrocławska \\ Wydział Budownictwa Lądowego i Wodnego \\ Katedra Mostów i Kolei \\ czeslaw.machelski@pwr.edu.pl \\ Maciej Hildebrand \\ dr inż. \\ Politechnika Wrocławska \\ Wydział Budownictwa Lądowego i Wodnego \\ Katedra Mostów i Kolei \\ maciej.hildebrand@pwr.edu.pl
}

DOI: $10.35117 /$ A_ENG_17_08_06

\title{
Strengthening of a road bridge due to a very large load
}

\begin{abstract}
Extremely heavy oversized transport is considered in the paper. Such oversized loads appears occasionally along the road network due to the restrictions of load capacity of bridges. The results of the analyses involved in the paper shows that old bridges as well as new ones are not adapted to such oversized loads. The strengthening or reconstructions of structural elements are required as presented in the paper. The final remark refers to the administrative understanding of the load capacity of the bridge which is based on the total weight of a vehicle. Such approach of the load capacity is not precise.
\end{abstract}

Keywords: Road bridge; Large load; Strengthening

\section{Operating loads on roads and bridges}

In the operation of road transport infrastructure, the main burden are motor vehicles. It is one of the types of bridge variable loads called the mobile load in standards [7, 8]. The basic technical characteristics of vehicles are their total mass $M$. This is the basis for the administrative qualification of the usable carrying capacity of bridges [7]. In the case of vehicles with large masses, it is advantageous to distribute the mass $M$ for many axles and wheels, as shown in figure 1. In road and rail practice, the loads on the $Q$ axis are also given. In the safety assessment of the main girders, the geometrical relations between the load diagram and the structure diagram are significant. bridge: the arrangement of axles and their mutual distances along the road. In road vehicles, as in Figure 1, the axle is a series of wheels located in a straight line perpendicular to the direction of travel. In the case of the safety assessment of the deck elements, it is essential to load the $P$ road with single wheels on the vehicle. The $P$ and $Q$ values are also important when checking the load-bearing capacity of road pavements.

Examples of the heaviest motor vehicles are discussed in $[7,3]$. The group of construction vehicles includes, among others car lifts, e.g. Grove RT 1650 with a mass $M=106.8$ tons. Multi-axle trailers drawn by a car, as in Fig. 1, are a frequent load on bridges, and their weight with the tractor reaches $M=210$ tons [7]. In some cases, a heavy item is transported on a trailer, e.g. a transformer with the total weight of a set with a tractor and a pusher of $M=414$ tons [6]. Record transport system with its own propulsion with a total weight (with load) $M=$ 637 tons traveled in 2016 over the bridge on Brzeźnica in Płock. The largest known load located entirely on the bridge over Whitehorse Creek in the state of Alberta (Canada) with the 
span $L=24$ m was an excavator with a mass $M=1144$ tons [1]. The ground and shell structure of this facility was specially adapted to this load.
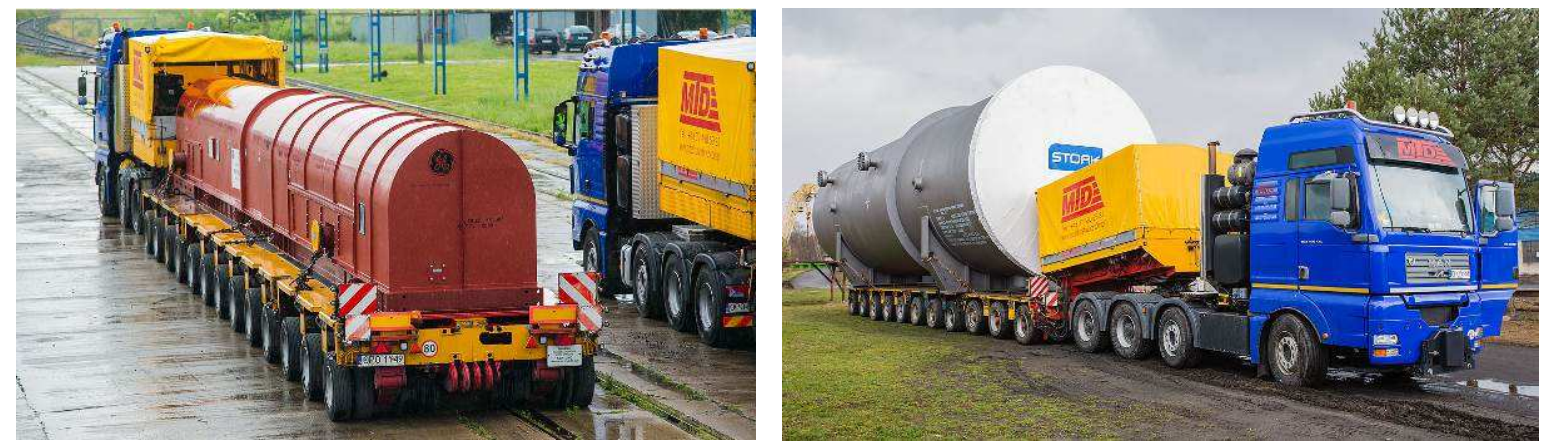

1. Non-normative transport carried out on public roads (www.mtdskuratowicz.pl)

\section{Design loads of bridge structures}

Bridge facilities of high communication importance are checked for the possibility of passing military vehicles of class 150 and class 100, in accordance with the NATO standard (Stanag 2021). These are the columns of vehicles with a maximum mass $M=151.3$ tons [4, 7]. As a design load of road bridges, the LM-1 load pattern is now introduced [8] shown in Figure 2. It consists of two types of loads: superficial UDL and the tandem of concentrated forces TS. The dynamic surplus is included in the load. The location of these loads is supposed to cause unfavorable internal forces in the analyzed element of the bridge structure. Each of the basic values is adjusted by the adjustment factors included in the table in Figure $\mathbf{2}$ as the values of $\alpha_{\mathrm{Q}}$ and $\alpha_{\mathrm{q}}$. This arrangement of loads already applies in European countries, including the individual National Annex, given in Table 1.
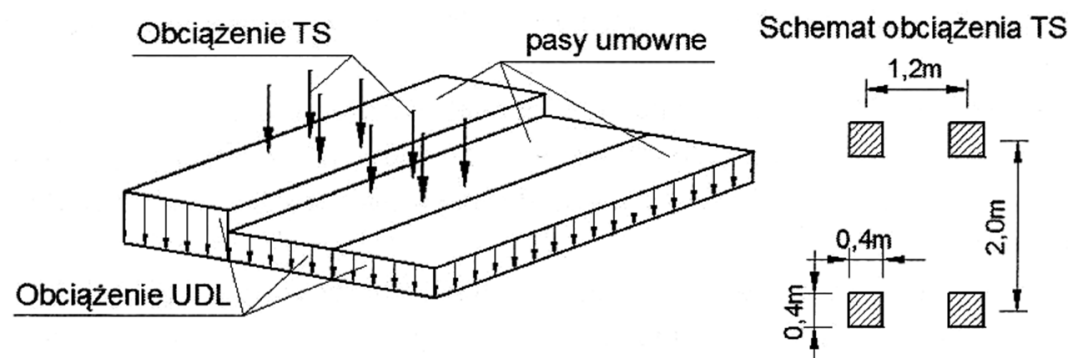

\begin{tabular}{|c|c|c|}
\hline $\begin{array}{c}\text { Numer } \\
\text { pasa jezdni }\end{array}$ & $\begin{array}{c}\text { Obciążenie } \\
\text { TS (na oś) } \\
{[\mathrm{kN}]}\end{array}$ & $\begin{array}{c}\text { Obciążenie } \\
\text { UDL } \\
{\left[\mathrm{kN} / \mathrm{m}^{2}\right]}\end{array}$ \\
\hline 1 & $300 \alpha_{\mathrm{Q} 1}$ & $9,0 \alpha_{\mathrm{q} 1}$ \\
\hline 2 & $200 \alpha_{\mathrm{Q} 2}$ & $2,5 \alpha_{\mathrm{q} 2}$ \\
\hline 3 & $100 \alpha_{\mathrm{Q} 3}$ & $2,5 \alpha_{\mathrm{q} 3}$ \\
\hline Pozostałe pasy & - & $2,5 \alpha_{\mathrm{qi}}$ \\
\hline Obszar pozostały & - & $2,5 \alpha_{\mathrm{qr}}$ \\
\hline
\end{tabular}

2. LM-1 [8] load model 
Tab. 1. Adjustment coefficients $\left(\alpha_{\mathrm{Q}}\right.$ and $\left.\alpha_{\mathrm{q}}\right)$ in National Annexes

\begin{tabular}{|c|c|c|c|c|c|c|}
\hline \multirow{2}{*}{ State } & \multicolumn{3}{|c|}{ For TS load on roadways, $\alpha_{\mathrm{Q}}$} & \multicolumn{3}{c|}{ For UDL load on roadways, $\alpha_{\mathrm{q}}$} \\
\cline { 2 - 7 } & $\mathrm{i}=1$ & $\mathrm{i}=2$ & $\mathrm{i} \geq 3$ & $\mathrm{i}=1$ & $\mathrm{i}=2$ & $\mathrm{i}>2$ \\
\hline Germany & 1 & 1 & 1 & 1,33 & 2,4 & 1,2 \\
\hline Netherlands & 1 & 1 & 1 & 1,15 & 1,4 & 1,4 \\
\hline France & 1 & 1 & 1 & 1 & 1,2 & 1,2 \\
\hline Poland* & 1 & 1 & 1 & 1 & 1 & 1 \\
\hline Belgium & 1 & 1 & 0 & 1 & 1 & 1 \\
\hline England & 1 & 1 & 1 & 0,61 & 2,2 & 2,2 \\
\hline Denmark & 1 & 1 & 1 & 0,67 & 1 & 1 \\
\hline Slovakia & 0,9 & 0,9 & 0,9 & 0,9 & 1 & 1 \\
\hline $\begin{array}{c}\text { Czech Re- } \\
\text { public }\end{array}$ & 0,8 & 0,8 & 0,8 & 0,8 & 1 & 1 \\
\hline
\end{tabular}

* Austria, Bulgaria, Croatia, Greece, Latvia, Hungary, Italy, Romania

Comparing the values of adaptation coefficients given in Table 1, it appears that German bridges will be adapted to the greatest operational burdens. A large group of countries accepting coefficients worth 1 is also Poland.

\section{Comparison of the effectiveness of standard and heavy vehicle loads}

The analysis of the effectiveness of the loads provided for in the Eurocodes [8] was carried out on the example of a bridge over the Brzeźnica river in Płock [3]. The general view of the bridge is shown in Fig. 3, and the view from the underside of the span - in Fig. 4. Both photographs were taken after the reconstruction of the building. The load-bearing structure of the analyzed object consists of 8 HEB 700 steel beams with a spacing of $b=1.15 \mathrm{~m}$ and their numbering as shown in Figure 5. The beams are braced with each other by light lattice crossings from angles. The bridge is a reinforced concrete slab with a thickness of approximately $t$ $=17 \mathrm{~cm}$, bold in the area of pavements up to approximately $t_{1}=40 \mathrm{~cm}$. Overall width of the platform $B=10.40 \mathrm{~m}$, roadway width $B_{\mathrm{j}}=6.94 \mathrm{~m}$, usable width of bilateral pavements $B_{\mathrm{c}}=2$ $\times 1.5 \mathrm{~m}$. The span is supported on massive abutments. and on additional intermediate, steel and frame supports that have been built in to adapt the facility to increased loads. The structural layout of the bridge is made up of steel beams with a concrete platform slab. The current span of the main bridge span $\mathrm{L}_{\mathrm{t}}=13.10 \mathrm{~m}$, and the length of the superstructure in the axes of supports at the abutments $\mathrm{L}_{\mathrm{c}}=16.84 \mathrm{~m}$. 


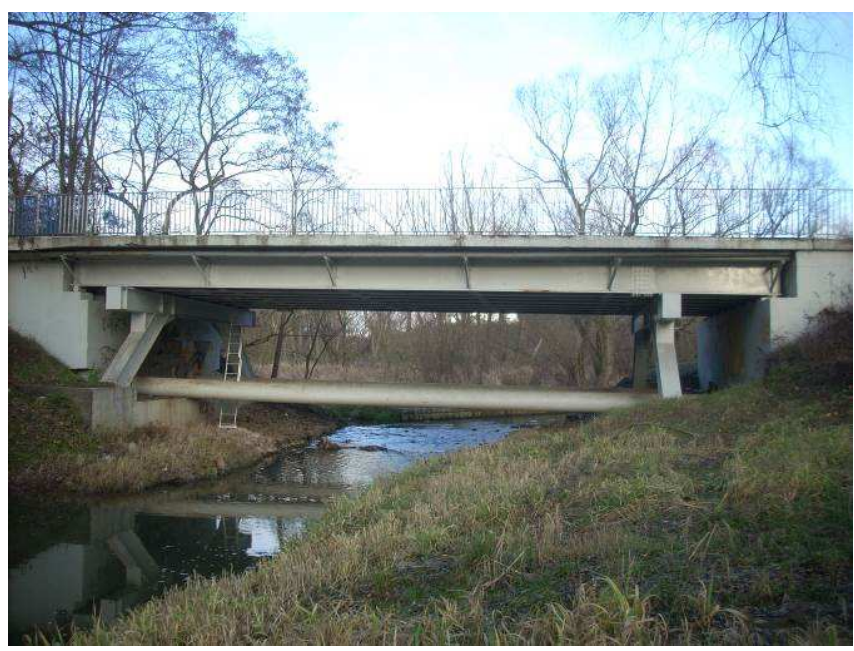

3. General view of the bridge after strengthening

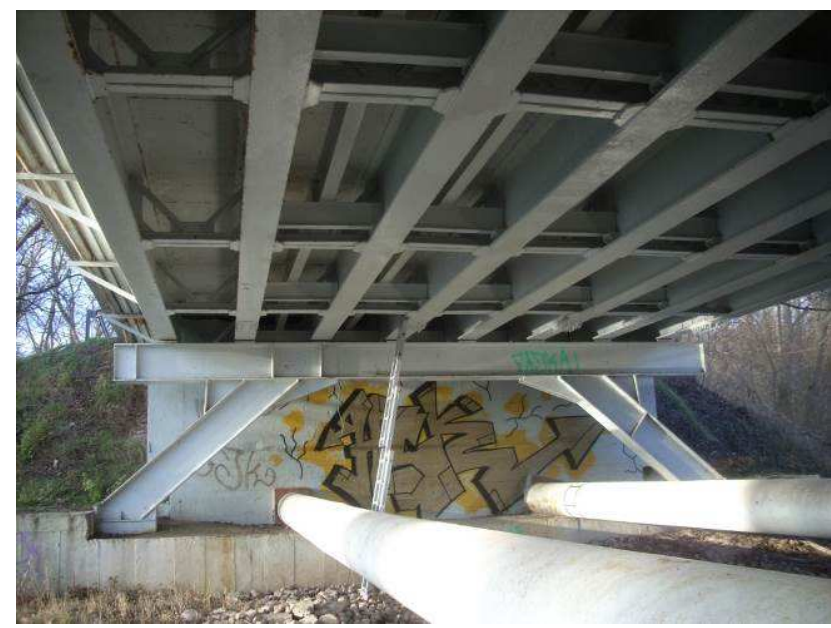

4. The construction of the bridge in the view from the underside of the span after strengthening

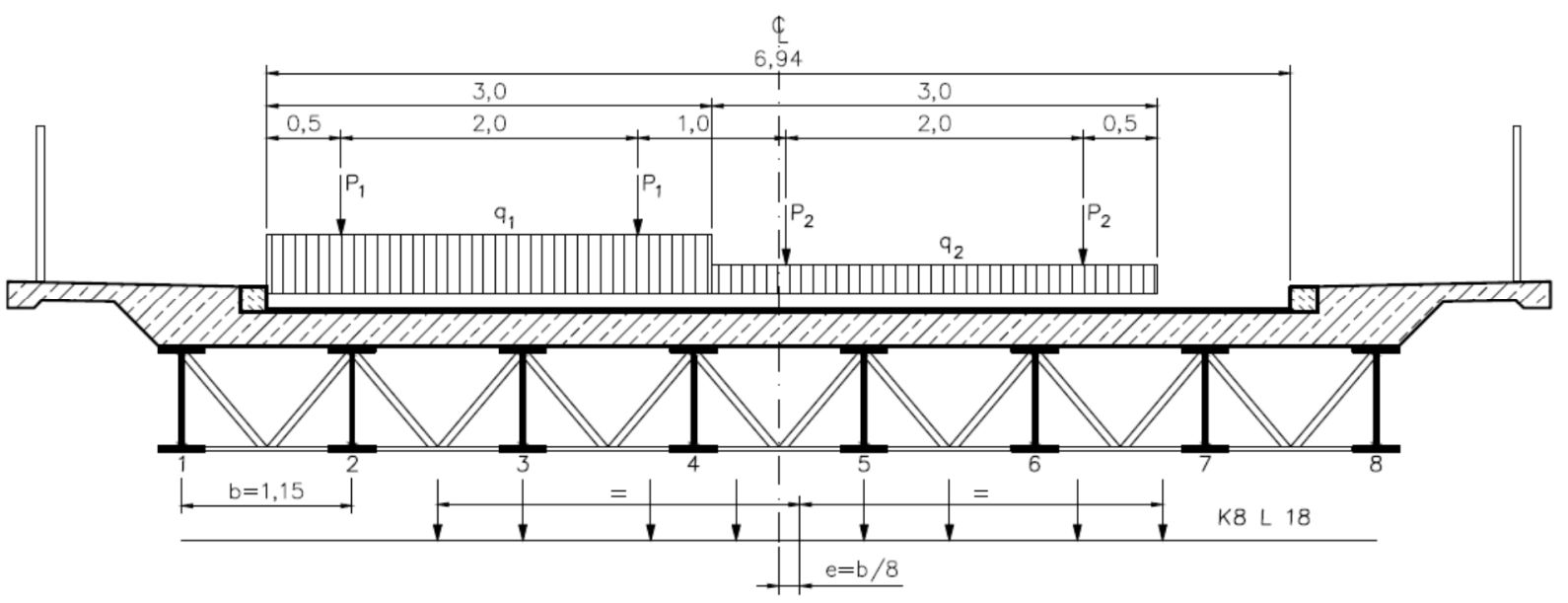

5. Location of loads in the cross-section of the bridge 
The bridge was originally a single-span structure with a span of $16.82 \mathrm{~m}$. Due to the planned non-standard transports, the building was rebuilt in previous years. Two intermediate supports were built in order to reduce the maximum span from 16,8 to $13.10 \mathrm{~m}$. Other works were also carried out.

In the spring of 2016, there was a need to transport an element of an industrial installation with a very large mass, fig. 6. The self-propelled chassis (with self-propelled) chassis was assembled from two vehicles with a total number of 144 wheels. The total mass of the vehicle with the load reached $M=637 \mathrm{t}$. The width of the occupied space on the roadway was about 5.6 ma length $L_{\mathrm{o}}=29.6 \mathrm{~m}$. The total mass of the unit with the load was evenly distributed on 18 axes with an emphasis on the axis $Q=354 \mathrm{kN}$ distributed over eight wheels with a pressure of $P=44.25 \mathrm{kN}$. The wheel pressure is regulated automatically in this vehicle.

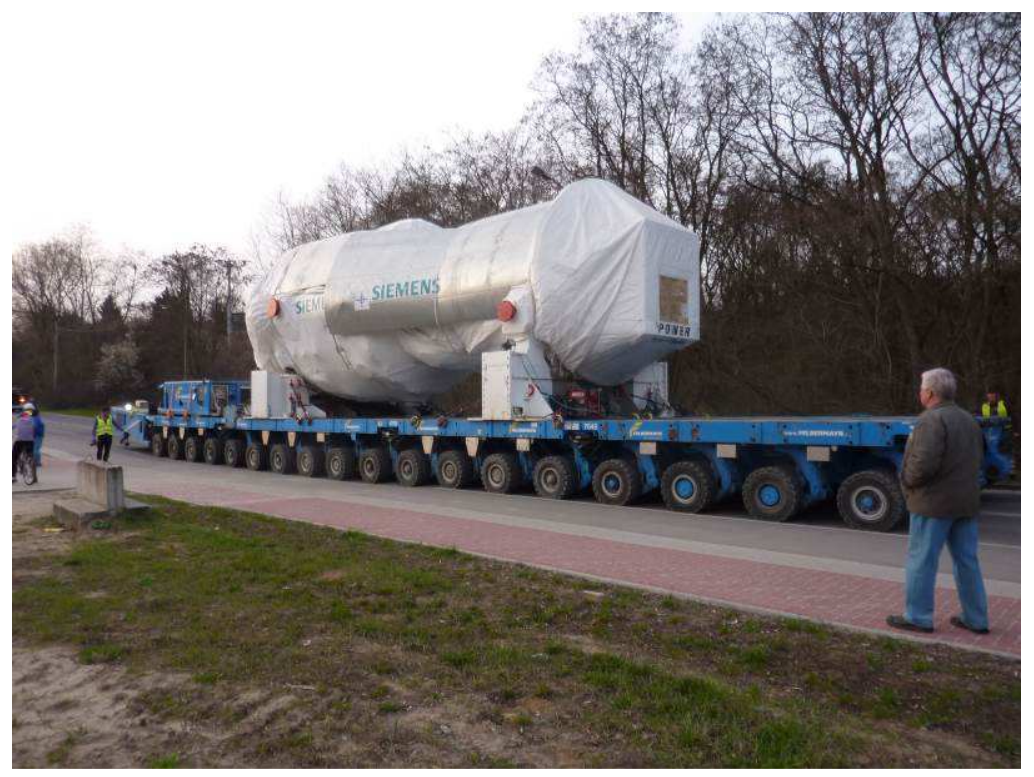

6. Transport with a weight of 636 tons carried out in Płock

The effects of impacts on the bridge of this vehicle were compared with the effectiveness of standard loads [8]. It was assumed in the analysis that the trajectory of the vehicle is offset from the road axis by $b / 8$, i.e. that the vehicle does not drive exactly in the axis of the road on the bridge.

The possibility of passing a vehicle with a mass of $637 \mathrm{t}$ by the bridge in question was considered, if it was designed according to Eurocode [8] with the largest values of adaptation coefficients adopted in Germany, as in TAB. 1. The analysis of girder 3 (Figure 4). Normal loads located in the cross-section of the bridge, unfavorably for the girder 3 in the form of concentrated forces are: $P_{1}=300 / 2=150 \mathrm{kN}$ and $P_{2}=200 / 2=100 \mathrm{kN}$. Loads are distributed with the value of $q_{1}=9 \cdot 1,33=12 \mathrm{kN} / \mathrm{m}^{2}$ and $q_{2}=2,5 \cdot 2,4=6 \mathrm{kN} / \mathrm{m}^{2}$. Figure 7 shows the lines of influence of the transverse distribution of loads concerning girders marked with numbers 2 , 3,5 , (Fig. 4). As a result of the transverse load distribution, a concentrated load $P=86.75 \mathrm{kN}$ and distributed $q=9.06 \mathrm{kN} / \mathrm{m}$ for the girder was obtained. 3 . Bending moment in the middle of the span extent 3 from both types of TS and UDL forces, i.e. from the standard load [8], (with a span length of $16.82 \mathrm{~m}$ ), is

$$
M_{E N}=678,4+221,0=899,4 \mathrm{kNm} \quad .
$$




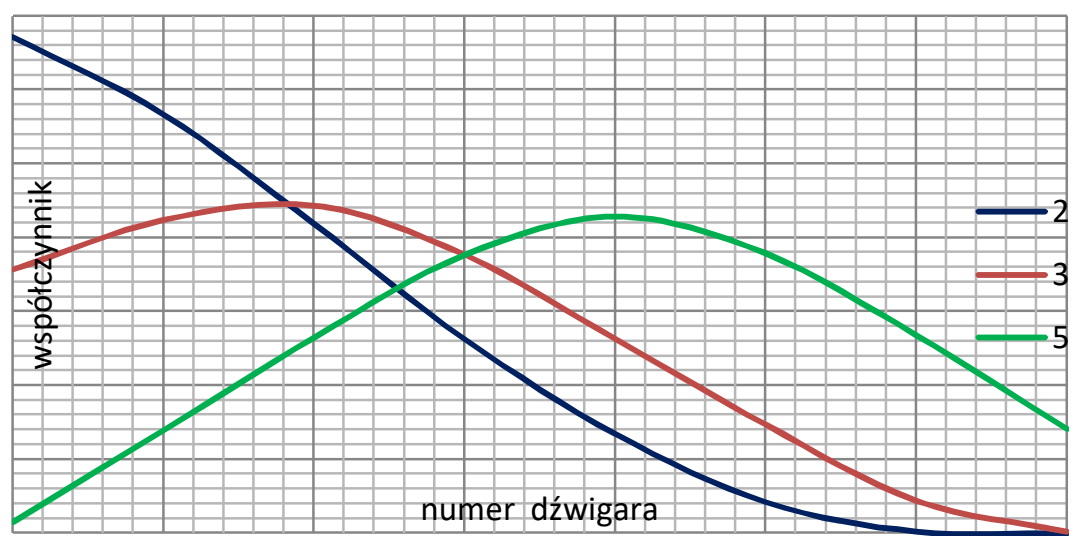

7. Lines of influence of transverse distribution of load. Numbers 2, 3, 5 indicate the main girders of the spans affected by the impact lines

The proportion of components from $P$ and $q$ in (1) is $678.4 / 221.0=3.07$. Thus, the effectiveness of tandem TS forces is three times greater than the efficiency of distributed UDL loads. In bridges of small spans, this proportion is higher [7], hence the general conclusion that in most bridges of small and medium spans this quotient will be similar, as the adjustment coefficients included in Table 1 for TS forces are in most cases equal to 1 . Significant differences will be referred to bridges with large spans for which UDL load is of great importance, and there is also a significant variation in the value of adjustment coefficients in National Annexes referred to in Table 1

The present oversized vehicle total weight $\mathrm{M}=637$ tones passing through the bridge analyzed Plock causes internal forces other than the load by standards [8]. As a comparative criterion, the maximum bending moment in the steel beams of the bridge spans was assumed. In the first step of the analysis, it was assumed that the bridge is in its original state, i.e. before reconstruction. At the time, the bridge structure consisted of one span supporting the span $\mathrm{L}_{\mathrm{t} 1}$ $=16.84 \mathrm{~m}$. It was assumed that the vehicle travels along the axis of the bridge, with a slight deviation in relation to the road axis $e=b / 8$. The analysis of the girder marked with number 5 . The replacement load on the girder 5, including the transverse load distribution is

$$
p=\frac{354 \cdot 1,333}{8 \cdot 1,4}=42,13 \mathrm{kN} / \mathrm{m}^{2}
$$

Thus the bending moment calculated in the middle of the span is

$$
M_{p}=\frac{42,13 \cdot 16,84^{2}}{8}=1493 \mathrm{kNm}
$$

Comparing $M_{\mathrm{EN}}(1)$ and $M_{\mathrm{P}}(3)$ it is evident that even currently designed bridges for the highest load (German) are not adapted to transport large non-standard loads. This note also applies to the design values of moments when load factors 1,35 (normal load) and 1,15 (exceptional load) are taken into account. Therefore, to carry out such transport it is necessary (and will be in the future) to strengthen the structure. A similar conclusion was also applied to a bridge suspended by the Vistula River in Płock [4] with a span $L=375 \mathrm{~m}$. Also, in this case, the potential passage of a non-normative vehicle with a weight similar to that of the vehicle analyzed in this article would not be safe

\section{Strengthening the bridge structure}

Strengthening of bridges due to road transport of large loads is economically justified. Paper [6] shows an example of transporting a transformer on a trailer with the weight of a set with a 
tractor and a pusher, $M=414$ tons. In the object, after which the passage took place, the span of the composite construction was reinforced, which was obtained with the use of external compression.

A small bridge across Brzeźnica in Płock is an interesting example of a small object of great economic importance. The facility is located in the network of city streets. Car traffic on the bridge is small, but the bridge is located along the road connecting the transshipment site located by the navigable river with a large production plant, to which the elements of industrial installations are transported by combined transport, i.e. by water and land. Due to its location and use - to (sporadically) transport heavy loads - the bridge structure has been adapted in the past [3]. The current shape of the object (after reinforcement) is shown in Figures 3 and 4. The construction changes listed below have been introduced.

- The platform has been strengthened by the installation of additional longitudinal beams between the main girders. Their task is to reinforce the platform due to high $P$ wheel loads in non-standard vehicles.

- Between the outposts, an additional two intermediate supports were built on separate pile foundations. On them are placed special, small-sized tangential bearings from packages of small flat bars. In the design assumptions, the original load-bearing structure does not load bearings over intermediate supports (there is a clearance of about $2 \mathrm{~mm}$ ). Therefore, the additional support is effective only at significant operational loads.

- The bridgeheads were stretched out with steel pipes. They are supposed to protect bridgeheads against the effect of increased ground pressure in the situation of high load on the back.

\section{Analysis of safety passage}

As a result of the reconstruction [3] undertaken to enable conducting non-normative transports, a structure was created with a three-span static scheme and spans: $L_{1}=1,40 \mathrm{~m}, L_{2}=$ $13,10 \mathrm{~m}, L_{3}=2,34 \mathrm{~m}$. Each intermediate support is a frame system. The three-span construction model is appropriate for heavier loads, e.g. a group of trucks. In the case of low-intensity operational loads, e.g. passenger cars, an effective system is a simple system, i.e. a beam with a freely supported scheme with a span $L_{t l}=16.84 \mathrm{~m}$. When the loads are large, as in the analyzed case, the appropriate span model is a one-sided bond diagram, i.e. a statically determinate system in the form of a beam with a span $L_{2}$ with brackets with lengths $L_{1}+\mathrm{c}$ i $L_{3}+\mathrm{c}$, thus without outer supports (abutments), when $c=0.2 \mathrm{~m}$, (c is the distance from the bearing axis on the abutments to the end of the supporting structure

Under such conditions, the expected bending moment was calculated in one of the span beams under a vehicle load with a total weight $\mathrm{M}=637 \mathrm{t}$.

The value of the bending moment in the girder 5 and the cross-section $\mathrm{x}=6.0 \mathrm{~m}$ distant from the additional support from the side of the span $L_{1}$, when the static scheme of the freesupported beam with supports is adopted, is

$$
M=\frac{g+p}{2} x\left(L_{2}-x\right)-M_{2}=\frac{13,01+42,13}{2} 6(13,1-6)-28,25=1146,2 \mathrm{kNm}
$$

where:

$$
\begin{aligned}
& M_{1}=\frac{g}{2}\left(L_{1}+c\right)^{2}=\frac{13,01}{2} 1,6^{2}=16,65 \mathrm{kNm} ; \\
& M_{3}=\frac{g}{2}\left(L_{3}+c\right)^{2}=\frac{13,01}{2} 2,54^{2}=41,97 \mathrm{kNm} ; \\
& M_{2}=M_{3}+\left(M_{1}-M_{3}\right) \frac{x}{L_{2}}=28,25 \mathrm{kNm} .
\end{aligned}
$$


The value of the bending moment given in (4) also takes into account the permanent loads of the main girder $\mathrm{g}=13.01 \mathrm{kN} / \mathrm{m}$. In the same bridge but before its reinforcement the value of the maximum moment would be

$$
M=\frac{g+p}{8} L^{2}=\frac{13,01+42,13}{8} 16,84^{2}=1955 \mathrm{kNm} ;
$$

so about $70 \%$ more. It was assumed in the calculations that there is no reliable bond between beams and plate. Normal stress in the HEB 700 steel beam in the absence of anastomosis is

$$
\sigma=\frac{1,1462}{0,00734}=156,2 \mathrm{MPa} \text {. }
$$

On the basis of the analysis, it was shown that despite the considerable size and weight of transport, as shown in Figure 6, passage through the facility after reconstruction is possible without excessive risk. The presented results of the computational analysis were used to issue an expert opinion on the possibility of carrying out the subject non-normative transport with a mass $M=637 \mathrm{t}$. This transport took place in the spring of 2016. The Brzeźnica bridge is currently operated as intended under normal car traffic.

\section{Summary}

The analyzed case of a very large vehicle weight may be another contribution to the discussion on the definition of the usable carrying capacity of bridges and its setting in an administrative mode as the total weight of the vehicle allowed to pass the bridge. The case analyzed in the work indicates a bright discrepancy between the administrative and the actual state of bearing capacity. It has been shown that it is possible to run a single heavy vehicle (however after a reinforced bridge) with a total weight of about 20 times the weight of vehicles allowed to move on typical bridges. Paper [6] shows an example of transformer transport with a mass $M=414$ tons after a facility with a capacity of 30 tons.

The authors realize that in the analyzed case of the bridge through Brzeźnica in Płock, the degree of using the load-bearing capacity of the structure (which even resulted in its potential local damage - but without a significant safety risk) was very large. However, it should be borne in mind that the bridge manager and transport company took into account the possible need to repair the bridge after the transport action. However, the problem of repair would be acceptable in the face of the strategic importance of the expanding large industrial plant with a key role in the economy of not only the city where it is located but also the economic life of the entire country.

In the case of bridges located in strategic places, it is possible to estimate the weight of heavy vehicles crossing the bridge using simple measurement systems that record selected parameters, eg forces, displacements [5]. Such a system can also be used while operating a non-standard set to verify the estimated utilization rate of the load, especially in the case of objects with a more complex scheme [4]. In the context of the granting of permits for nonnormative transport on public roads, it is important to determine the load-bearing capacity of damaged bridge spans. In such situations, it is possible and recommended to use expert tools specially designed for this purpose [2].

\section{Source materials}

[1] Bakht B.: Evolution of the design methods for soil-metal structures in Canada. Archives of Institute of Civil Engineering. No 12007 pp. 7-22.

[2] Bień J., Gładysz M., Kużawa M., Systemy ekspertowe w ocenie kondycji przęseł mostowych z uszkodzeniami, Przegląd Komunikacyjny, 9/2013, s. 18-25. 
[3] Hotloś Z.: Most przez rzekę Brzeźnicę w ciągu ul. Kazimierza Wielkiego w Płocku, Projekt wzmocnienia mostu - Obliczenia dodatkowe na obciążenie wyjątkowe 516 ton. Pracownia Projektowa Zbigniew Hotloś, Płock 2007.

[4] Machelski C., Hildebrand M.: Duże obciążenia dużego mostu. Seminarium Wrocławskie Dni Mostowe, Wrocław 29-30 listopad 2015 r. s. 525-532.

[5] Machelski C., Hildebrand M.: Estimation of influences on a cable-stayed bridge on the basis of force changes in the stays recorded by Monitoring System. Journal of Civil Structural Health Monitoring (2015) 5:1-9.

[6] Machelski C., Onysyk J., Prabucki P.: Wzmocnienie mostu zespolonego ze względu na przejazd nienormatywny, VIII Sem. „Współczesne metody wzmacniania i przebudowy mostów". Poznań 9-10 czerwca 1998 s. 89-96.

[7] Machelski C.: Ruchome obciążenia obiektów mostowych. Dolnośląskie Wydawnictwo Edukacyjne, Wrocław 2015.

[8] PN-EN 1992-2-2010. Eurokod 1: Oddziaływania na konstrukcję - Część 2: Obciążenia ruchome mostów. 